\title{
Intrajoint Inoculation of Myc. leprae and lepraemurium to the Mouse
}

\author{
Masahiro NAKAMURA and Yutaka Mitsufuji \\ Department of Microbiology, Kurume University \\ School of Medicine
}

The fate of Myc. leprae and lepraemurium followed by the mouse-joint inoculation which had not been attempted before was observed and the results obtained demonstrated that Myc. lepraemurium developed well in the foot-joint cavity. The part of the bacillus multipliaction was the joint-sack, not joint fluid. No additional effects of mucine, crystal violet, and trypan blue to the bacillary suspension for stimulating the development of the bacilli were observed.

In the case of Myc. leprae experiments, there were no increases of the bacilli in this part, when observed direct smear preparations. However, the further experiments shoud be needed for the determination of the increases of the bacilli, because, in this experiment, the number of bacilli in the materials was not mathematically calculated. 


\title{
攋菌のマウス関節腔内接種実験
}

\author{
中 村搨弘 - 光藤坦
}

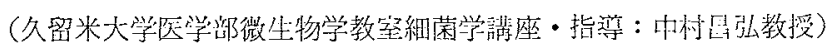

（受付 1965年 8月10日）

種々なるルートにより鼣面菌をマウスに接種した実験 成績1)の中で, 足関節腔内接種において鼠瀬菌の著明な 增菌が認められたてとを報告した。

今回は今まで武みられたことのないとの鼠瀬菌の関節 䑚内接種成績の確認とそ机に関推した実験，並に人藾菌 を足関節内に揬㮔した場合の成結について報告する。

\section{実験材料並に方法}

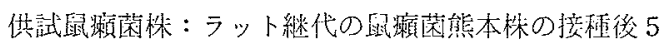

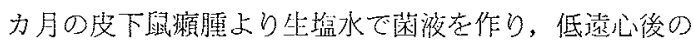
上清老接種材料として用いた。この時の菌数は約 $3.7 \times$ 108/ml であった。

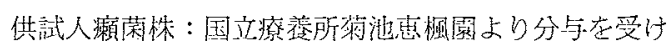
た江口怢の結節を俩观置のまま生塩水で乳剂とし，その 遙心上清をトリプシン消化，デゾキシコール酸ソーダ

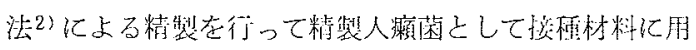
いた。菌数は約 $1 \times 10^{6} / \mathrm{ml}$.

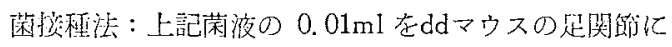

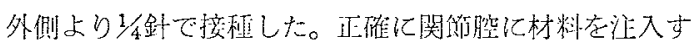
万為の技術の翼得は甬めレントゲン写真によって確めて

行った。（写真(1)(2)参照)

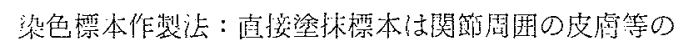
組織を法来るだけ剥湤し関節の接合亚をハサミで二分 し，接合西直接スライドグラスに淦抹し，乾燥固定後 Zieh1-戸田法3で染色した。

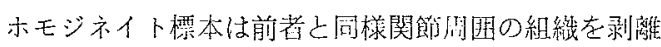
したのち関算，接合面より離狄たところより両端を切断 し，関節部を残し，乙札を润菌乳鉢中ですりつぶし，関 節 1 個当り $0.5 \mathrm{ml}$ の生坋水に浮遊させ，析く静罢し虺 心することなく上清索栖海白金耳でとりそのままスライ ドグラスに塗抹し，自然に附希した材料を乾燥させ，固

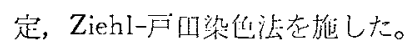

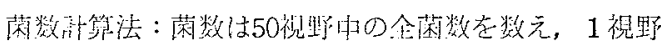
当りの平均菌数で示した。

佔武桨剂：トリパン青 (Merck筡)，クリスタル紫（和 光純薬）及びグラヌラルムチン（和光純藻）はそれぞ机 $0.2 \%, 0.00002 \%$ 及び $0.02 \%$ 烝溜水淮滩として使用し た。減藏は低溜滅菌によった。

\section{実験成績}

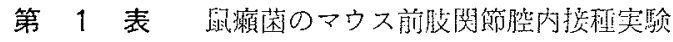

\begin{tabular}{|c|c|c|c|c|c|c|c|c|c|c|c|}
\hline \multirow{2}{*}{ 接 } & \multirow{2}{*}{ 䅖 } & \multirow{2}{*}{ 位 } & \multirow{2}{*}{ 㭢朴作製法 } & \multirow{2}{*}{$\begin{array}{c}\text { マウス } \\
\text { No. }\end{array}$} & \multicolumn{7}{|c|}{ 㑕 程 後 の日数 (週) } \\
\hline & & & & & 0 & 2 & 4 & 6 & 8 & 10 & 12 \\
\hline 右 & 前 & 肢 & ホモジネイト & $\begin{array}{l}1 \\
2\end{array}$ & & $\begin{array}{l}0.3 \\
0.4\end{array}$ & $\begin{array}{l}0.3 \\
0.5\end{array}$ & $\begin{array}{l}3.1 \\
3.7\end{array}$ & 26.3 & $\infty$ & $\infty(H)$ \\
\hline 村 & 関 & 仰边 & 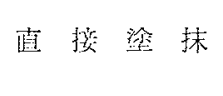 & $\begin{array}{l}1 \\
2\end{array}$ & 1 & $\begin{array}{l}2.6 \\
0.3\end{array}$ & $\begin{array}{l}0.8 \\
0.4\end{array}$ & $\begin{array}{l}1.5 \\
6.0\end{array}$ & 1.2 & $\begin{array}{l}2.8 \\
\infty\end{array}$ & 80.3 \\
\hline 左 & 前 & 肢 & ホモジネイト & $\begin{array}{l}1 \\
2\end{array}$ & & $\begin{array}{l}0.4 \\
0.2\end{array}$ & $\begin{array}{l}0.5 \\
0.8\end{array}$ & $\begin{array}{l}4.1 \\
2.3\end{array}$ & 11.4 & 55.7 & $\infty(H)$ \\
\hline 肘 & 関 & 筑 & 直 接 塗 抹 & $\begin{array}{l}1 \\
2\end{array}$ & 5.3 & $\begin{array}{l}0.5 \\
1.9\end{array}$ & $\begin{array}{l}0.2 \\
0.6\end{array}$ & $\begin{array}{l}1.0 \\
3.0\end{array}$ & 7.7 & $\begin{array}{l}\infty \\
9.8\end{array}$ & $\infty$ \\
\hline
\end{tabular}

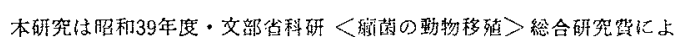

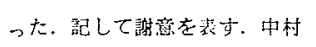


1. 鼠㴭菌のマウス前肢肘関節腔内接種実験

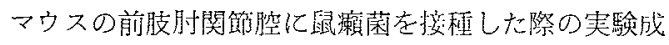
續は第 1 表の如くである。これによると左存いずれの䏘 関節腔にも経时们に菌の增列が認められた。なお，菌の 増殖判定には直接塗抹摽本よりあホモジネイト標本の方

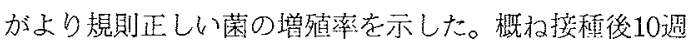
目には菌数を数え得如程に橧柕する。

2. 鼠瀬菌のマウス後肢足関節腔内接種実験

同様の実験を後肢足関節腔内接種によって行った成綪

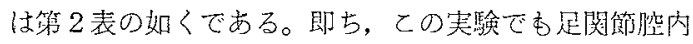
に拈いて菌の経特的增列が認められた。前实験上同様に

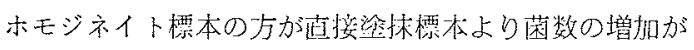
経日的に規則正しかった。

また，対照として後肢外側皮下に撄極した㯏合の菌の

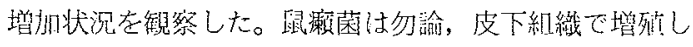
たが，堛殖度は関節臆内控柯の方がすぐれていた。

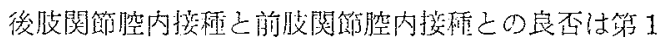

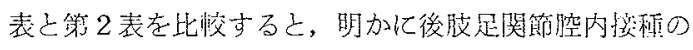

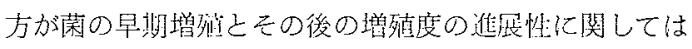

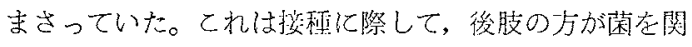
筑腔内によく注入汕来るためであるう。

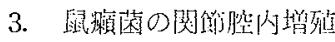

阅節腔内に接程された鼠旗菌が四節腔のいずれの部位

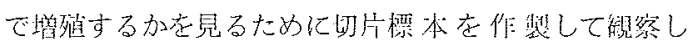

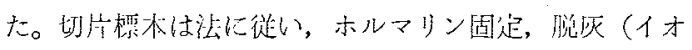

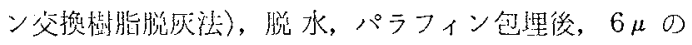

厚さの断搮本を作製し，染色はZiehl 染色後マイヤー 染化老行った。な招材料は接㮔後 6 週目，10週目の前肢 肘関節，後肢足闺節范肥いた。

符 3，4，5, 及び 6 四に亦すように，6週目の前肢 则関節においては，菌は带端部の硝子軟搰部には存在せ ず，関節囊之りわけ滑膜層之岕われる所に多くの抗酸菌 を認めた。また関䬦蹰の一部は肥厚しており，同部位に

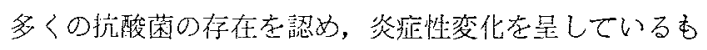

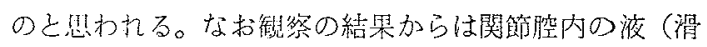
液）中に抗陵菌が存任したと䍐わさるような所見は認め られなかった。

艒 7 及び 8 図に示すように, 10週目の後肢足関節の切 片栖本でも，6週目の场命と同㥞の所見を得た。即ち，

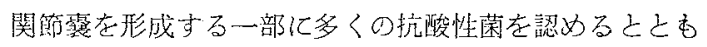
に, 同部任組織に数いては, 㹩度のセンイ化，即ち結合 組蟣の增歹が見られ，椅门或は類门を呈するセンイ芽細 胞亡組織球, 少数のリンパ球，陮核維顺，また一部では

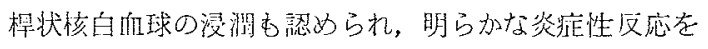
示していた，てれに厓して外们の骨柲筇には炎症性变化 毛菌の集团も認めなかった。また，内侧では関節部骨端

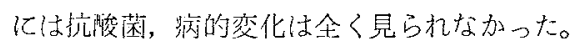

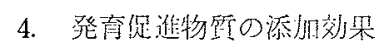

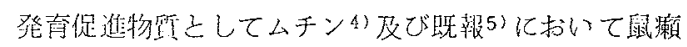
の発症在促したクリス多ル紫在用いた。ムチン或はクリ

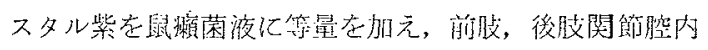

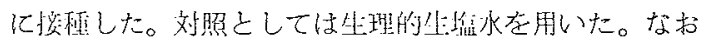

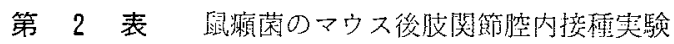

\begin{tabular}{|c|c|c|c|c|c|c|c|c|c|c|c|}
\hline \multirow{2}{*}{ 接 } & \multirow{2}{*}{ 程 部 } & \multirow{2}{*}{ 位 } & \multirow{2}{*}{ 橿本作製法 } & \multirow{2}{*}{$\begin{array}{c}\text { マウス } \\
\text { No. }\end{array}$} & \multicolumn{7}{|c|}{ 㑕稙後の口数 (週) } \\
\hline & & & & & 0 & 2 & 4 & 6 & 8 & 10 & 12 \\
\hline 右 & 後 & 肢 & ホモジネイト & $\begin{array}{l}1 \\
2\end{array}$ & & $\begin{array}{l}0.1 \\
0.7\end{array}$ & $\begin{array}{l}0 \\
0.3\end{array}$ & $\begin{array}{l}0.4 \\
0.9\end{array}$ & 9.5 & $\infty$ & $\infty(H)$ \\
\hline 题 & 闯 & 節 & 直掞梁抹 & $\begin{array}{l}1 \\
2\end{array}$ & 2 & $\begin{array}{l}1.5 \\
0.3\end{array}$ & $\begin{array}{l}0.3 \\
0\end{array}$ & $\begin{array}{l}3.4 \\
0.6\end{array}$ & 33.8 & $\begin{array}{c}16.9 \\
\infty\end{array}$ & 33.3 \\
\hline 左 & 後 & 肢 & ホモジホイト & $\begin{array}{l}1 \\
2\end{array}$ & & $\begin{array}{l}0.3 \\
0.1\end{array}$ & $\begin{array}{l}0 \\
0\end{array}$ & $\begin{array}{l}0.3 \\
0.4\end{array}$ & 3. 4 & 87.2 & $\infty(H)$ \\
\hline 足 & 関 & 節 & 伹接歭抹 & $\begin{array}{l}1 \\
2\end{array}$ & 1.6 & $\begin{array}{l}0.8 \\
0.8\end{array}$ & $\begin{array}{l}1.2 \\
0.4\end{array}$ & $\begin{array}{r}3.7 \\
22.7\end{array}$ & 41.9 & $\begin{array}{r}48.0 \\
1.7\end{array}$ & 83.7 \\
\hline 迎 & 後 & 波 & ホモジネイト & $\begin{array}{l}1 \\
2\end{array}$ & & $\begin{array}{l}2.6 \\
0.1\end{array}$ & $\begin{array}{l}0.3 \\
0.3\end{array}$ & $\begin{array}{l}0 \\
0.5\end{array}$ & 3. 0 & $\infty$ & $\infty(H)$ \\
\hline 外 & 侧 皮 & 下 & ホモジネイト & $\begin{array}{l}1 \\
2\end{array}$ & & $\begin{array}{l}1.5 \\
0.2\end{array}$ & $\begin{array}{l}0.4 \\
0.3\end{array}$ & $\begin{array}{l}0.2 \\
0.1\end{array}$ & 21.8 & 51.2 & $\infty$ \\
\hline
\end{tabular}


第 3 表 鼠癩菌のマウス网節腔内按㾏!

\begin{tabular}{|c|c|c|c|c|c|c|c|c|}
\hline \multirow{2}{*}{$\begin{array}{l}\text { 接 } \\
\text { 種 } \\
\text { 部 }\end{array}$} & \multirow{2}{*}{$\begin{array}{c}\text { 菌 液 }+ \\
\text { 等量 }\end{array}$} & & \multicolumn{2}{|c|}{ 挍 } & $\infty$ & \multicolumn{2}{|c|}{ 数 (邀) } & \multirow[b]{2}{*}{12} \\
\hline & & 0 & 2 & 4 & 6 & 8 & 10 & \\
\hline \multirow{3}{*}{$\begin{array}{l}\text { 前 } \\
\text { 娶 } \\
\text { 足 } \\
\text { 関 } \\
\text { 毁 }\end{array}$} & $\mathrm{NaCl}$ & 0.15 & 0.1 & 0.1 & 0.2 & 28.6 & 43.6 & $\infty$ \\
\hline & $0.02 \%$ ムチン & 0.2 & 0.3 & 0.3 & 0.8 & 30.8 & 12.3 & $\infty$ \\
\hline & $\begin{array}{l}0.00002 \% \\
\text { クリス } \text { タ }\end{array}$ & 0.18 & 0.1 & 0.2 & 1.0 & 39.6 & $\infty$ & $\infty$ \\
\hline \multirow{3}{*}{$\begin{array}{l}\text { 後 } \\
\text { 肢 } \\
\text { 足 } \\
\text { 闀 } \\
\text { 筑 }\end{array}$} & $\mathrm{NaCl}$ & 0.22 & 0 & 0 & 0.2 & 11.8 & 25.6 & 31.9 \\
\hline & $0.02 \% \Delta チ ン$ & 0.15 & 0.1 & 0.3 & 0.6 & 4.8 & 12.5 & $\infty$ \\
\hline & $\begin{array}{l}0.00002 \% 6 \\
y_{1} \text { 多 }\end{array}$ & 0.16 & 0.1 & 0.4 & 1.2 & 3.8 & 79.4 & 30.9 \\
\hline \multirow[t]{2}{*}{ 足 } & $\mathrm{NaCl}$ & 0.15 & 0.2 & 0.5 & 3.0 & 21.1 & 70.8 & 45.0 \\
\hline & $0.02 \% ム \mp ン$ & 0.26 & 0.2 & 1. 2 & 3.2 & 38.6 & $\infty$ & 31.6 \\
\hline 蹠 & $\begin{array}{l}0.00002 \% \\
\text { 月リスタ紫 }\end{array}$ & 0.95 & 1.0 & 0.3 & 1.9 & 7.5 & 6.3 & 14.7 \\
\hline
\end{tabular}

対照として足踣皮下接種㚖試みた。栖木作製はホモジネ イト標本を染色した。その成績は筙 3 表の如くである。 この成續によると，発症促進物䒈として加えたムチン及 びクリスタル紫は対照に比して蕃明には菌の增列を促さ なかった。しかし，強いていえば，関節腔内揬種ではク リスタル紫の添加は菌の增㱷を促進したようであった。 そして足蹠内接種ではムチン源加加良好な成績を示し た。

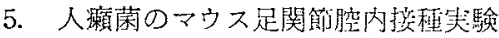

人瀬菌江口株の精製菌乳剂に等量の坐篮水，トリパン

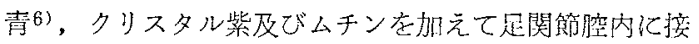
㻎する实験を試みた。実験成績は第 4 表の讬くである。 この際は按種して肴殺するまで 150 日以上経過した。祝 本は直搷準抹法によった。

これによると敬在性抗酸菌がいつれの標本にも置られ たが，そのうちのあるものには表示のように非抗酸性桿 菌が混在しているものもあった。散在性抗酸菌の量は少 く，増菌己して判定出来る程度ではなかった。

\section{若察}

ある病原体に詨して元来非感受性であるといわれてい る動物個体の中に感受性組織がかくされている可能性は 否定出来ない。適当な力法でその組織に嗃接, その病原 体を到達させ感染を試みるととにより，病原体の堌殖か 行われるととがある。神経親和性ウイルスといわ机てい る脳炎ウイルスのマウス脸内接種がをの最も良い例であ

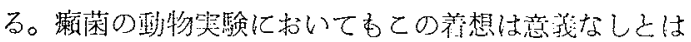
思われぬため，今国は今まで武みられたととのないマウ
第 4 表 癩菌のマウス足関節案内接租実驗

\begin{tabular}{|c|c|c|c|c|}
\hline $\begin{array}{l}\text { ライ菌十 } \\
\text { 等星 } 0 \\
\text { 下記溶液 }\end{array}$ & $\begin{array}{l}\text { 供試 } \\
\text { マウ } \\
\text { 数 }\end{array}$ & 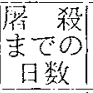 & 剖 検 所 見 & $\begin{array}{l}\text { 壃菌 } \\
\text { 档定 } \\
\end{array}$ \\
\hline 生 鼨 水 & 10 & 171 & 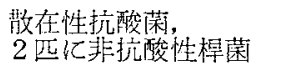 & 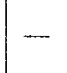 \\
\hline 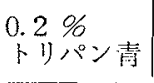 & 10 & 170 & $\begin{array}{l}\text { 散在性抗酸菌, 国時に } \\
\text { 多数の非抗酸性㮛䒩落 }\end{array}$ & - \\
\hline $\begin{array}{c}0.00002 \% \\
ク リ ス タ ル \\
\text { 紫 } \\
\end{array}$ & 11 & 155 & 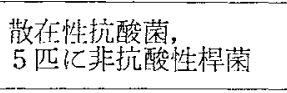 & \\
\hline 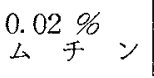 & 8 & 170 & 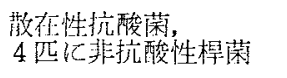 & \\
\hline
\end{tabular}

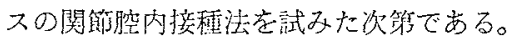

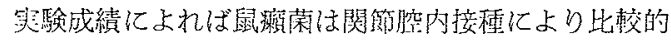
規则正しい增殖を示し，対照として行った皮下接種より 毛良好であった。ただこの場合，栖木作製にはホモジナ

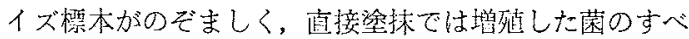
てを把握するととは伹来なかった。

関節腔内の增殖部位は関節霣であって，骨端部の硝子 软骨及び滑液中には菌の増㥀はなかった。これは渍菌が 增殖をするためには，一定の組䄉に寝生し增殖すること の要求赽示す向のであるう。

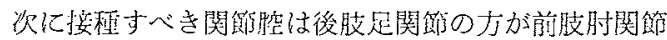
よりすぐれているようである。をれは恐らく菌を接種す る場命，前老の方がより寒易であり，菌が関節腔儿蕰接 注入されたもの之思われる。

発育促進物邱ししてクリスタル紫，ムチン，及びトり

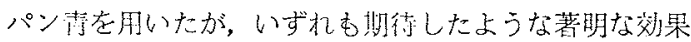


はなかった。瓦瀬菌で得た成紽を参考にして，人瀬菌を

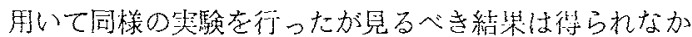

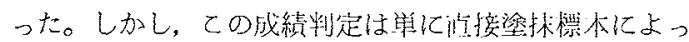
たのであるので, Shepardて が行ったような菌数獄測法 によ记ば或は何らかの結果が得られたかもしれず令後の 检刲にまちたいと惢う。

\section{結 論}

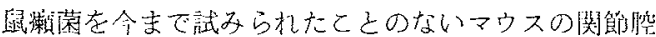

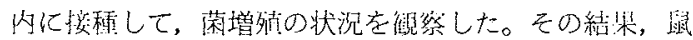

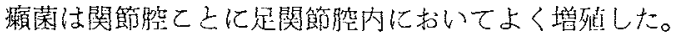

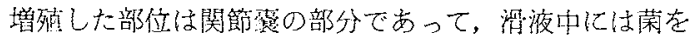
铅めなかった。発症促進物䓄上してムチン，クリスタル 紫及びトリパン青を那いたが見る心゙き刘果はなかった。

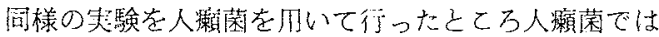

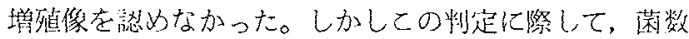

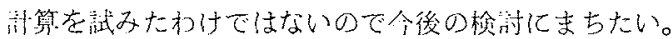

文献

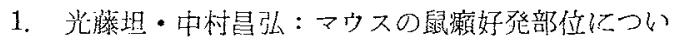
ての实験，レプラ 34, 287〜289, 1965

2.中村兒弘・上野由蔍：鼠獺菌の簢便日.つ無䒩的集 藏法， 月本縕菌学雑誌，18，75７9，1963

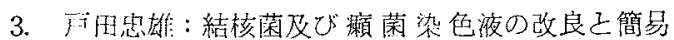
化，東京医事新誌，3064，3362，㕷和12

4. Wood, W. B. : Studies on the cellular immunology of acute bacterial infections, in The Harvey Lectures 1951-52. P. 87, Academic Press.

5.中村鼠张：鼠瀬菌の牛物学的性状関する研究，

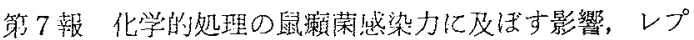
亏 $34,274 \sim 278,1965$

6. 太正雄・日干修一：人瀨及び鼠瀨の動物夷驗, レプラ $13,120,1942$

7. Shepard, C. C. : The experimental disease that follows the injection of human leprosy bacilli into foot-pads of mice. J. Exp. Med. 112, 445-454, 1960

\section{中村 ・ 光藤 論文附図}

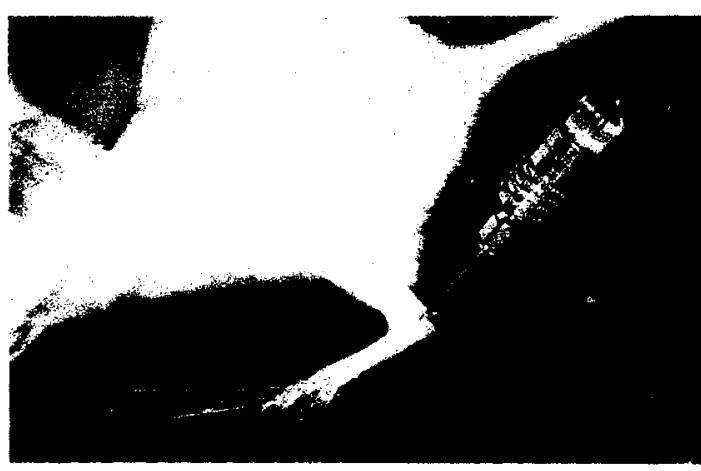

军真 1 鼠癩藏，人癩㭉のマウス足関節内接種

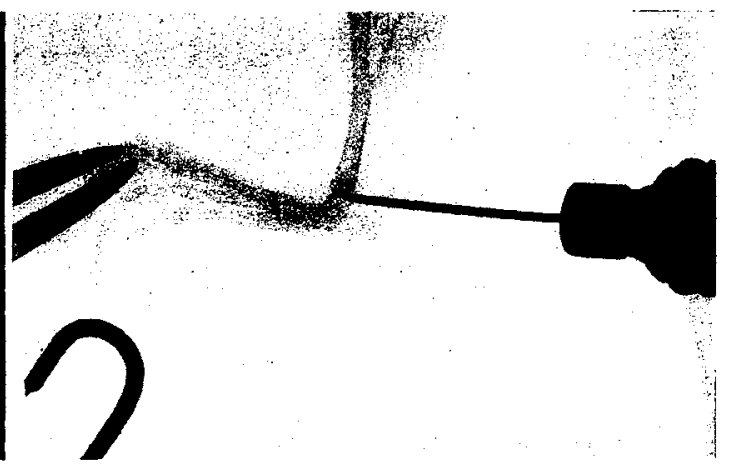

写真 2 獺菌のマウス足関節内接種（レントゲン写真） 

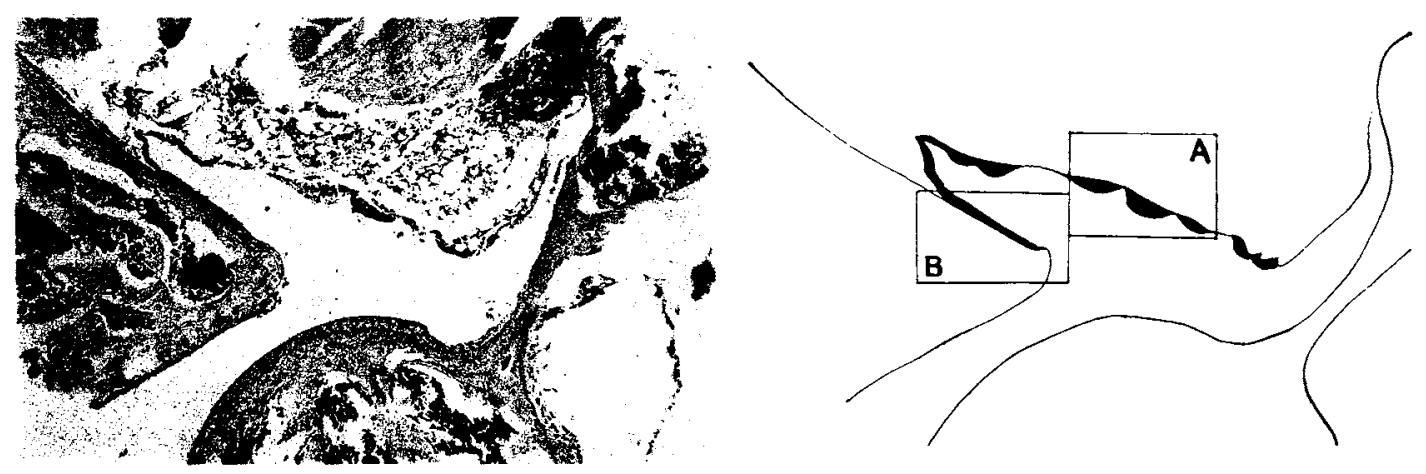

第 3 図 鼠癩菌のマウス前肢肘関節腔内接種による 接種後 6 週目の増菌所見

第4図左図組織切乡標木の説明図（黒色部莉集回）

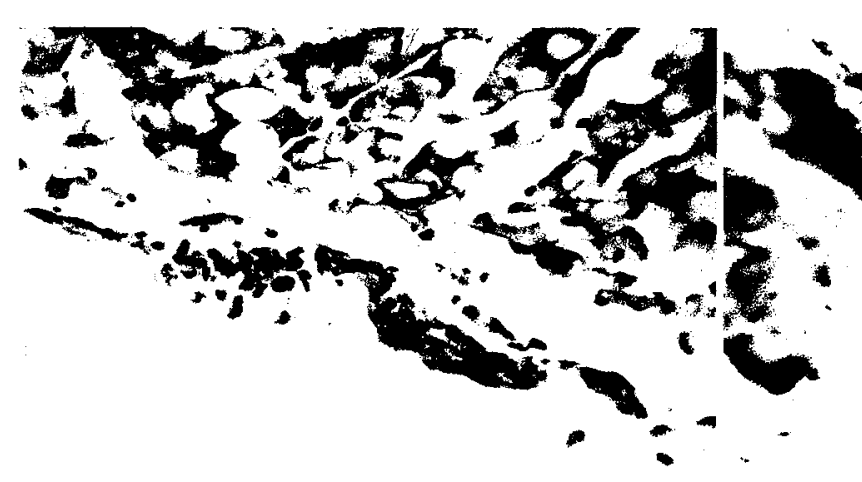

第5図（A）の部の拡大所見

第6図（B）の部の抬大所兒

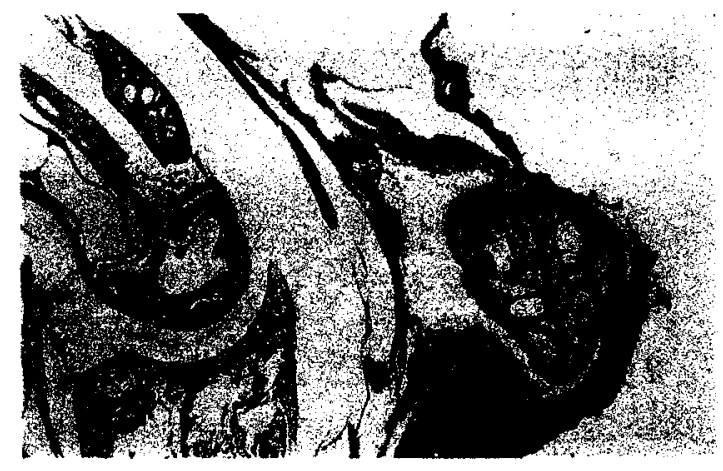

第 ๆ図 鼠瀬菌のマウス後肢足関節腔内接種による 接種後 10 週目の増菌所見

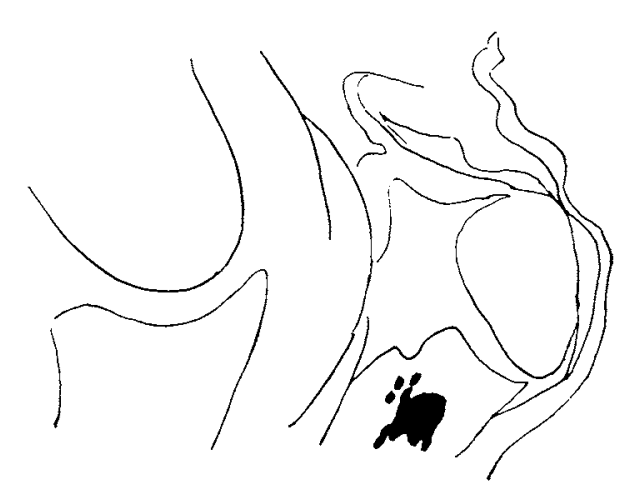

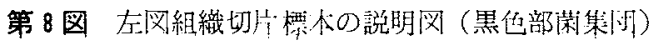

